\title{
Target points for professional educational organizations development in territories with special organization of production and residence
}

\author{
Tatiana Letaeva ${ }^{1, *}$, Vladimir Bazelyuk ${ }^{2}$, Elena Popova $^{2}$, Nadezhda Demina $^{2}$, and \\ Alexander Demin ${ }^{2}$ \\ ${ }^{1}$ Technological Institute, a branch of the National Research Nuclear University MEPhI, \\ Kommunistichesky Ave., 36, 624200 Lesnoy, Russia \\ ${ }^{2}$ South Ural State University (national research university), Lenin Str., 76, 454080 Chelyabinsk, \\ Russia
}

\begin{abstract}
The article defines the target points for the secondary vocational education organizations, located in territories that simultaneously have the status of "single-industry city", "closed administrative-territorial unit" and "advanced development zone" development (the cities of Seversk, Ozersk, Snezhinsk, Zheleznogorsk, Zarechny). Based on information and analytical materials for the training quality monitoring, vectors allowing these institutions to achieve high indicators of both "The national project "Education"" and the territorial development indicators values have been formed. The main designated target points are global trends, regional projects within the framework of Federal projects, priority economic activities in these territories, and the interests of city - forming enterprises.
\end{abstract}

\section{Introduction}

Scale projects for higher education modernization in the Russian Federation have been implemented for a long time, while global projects for secondary vocational education (SPE) development have been a priority for the last two or three years.

The defining vector for this system development is the targets set by the national project «Education» (implementation period 2019-2024). The national project includes ten Federal projects, three of which are aimed at modernizing secondary vocational education system: "Young professionals (improving the competitiveness of vocational education) », «Digital educational environment», «Every child's success». At the regional level, these projects were decomposed into regional ones and received indicators of achievement in accordance with the territorial strategic objectives of socio-economic development.

\footnotetext{
${ }^{*}$ Corresponding author: T.Letaeva@gmail.com
} 
The modern spatial organization of the Russian Federation is determined not only by regional division, but also by the presence of territories, characterized by specific features of production and residence.

The term «territory with a special production and residence organization» refers to a municipality whose socio-economic development is largely determined by a single cityforming enterprise presence and (or) presence of a special regime for the enterprises' and (or) objects' safe operation on its territory [1]. These areas include single-industry cities and closed administrative-territorial entity (CATE).

The list of single-industry towns is determined by the Russian Federation government order and includes 319 municipalities. These territories are characterized by a high concentration of labor resources in one enterprise (more than 20 percent of the average number of employees of all organizations operating in the municipality territory) and a high share of the enterprise's product in the municipality gross output.

The list of closed administrative-territorial entities is regulated by a government decree and includes 38 municipalities. Ten of them belong to the jurisdiction of «Rosatom» (SC «Rosatom») state corporation, because there are scientific and production facilities of nuclear energy on their territory. Seven of the ten «closed» «Rosatom» cities have the status of a «single-industry city».

Such «closed» cities as Zheleznogorsk, Ozersk, Snezhinsk, Zarechniy, Seversk, subordinated to «Rosatom» not only have the status of a "single-industry city», but also the «priority development area» (PDA) status, regulated by Federal law No. 473 dated 29.12.2014. Economic zones PDA are created to attract investment in high-tech industries organization.

Thus, special economic conditions have been created in these municipalities, they are crucial for the formation of both the overall socio-economic policy and regional target indicators for the national project «Education» implementation, since the vectors of industrial development in such territories require a special strategy for training middle-level specialists and qualified workers and employees.

Professional educational organizations operating in these municipalities do not have a unified approach to forming targets for the development of educational institutions, despite the fact that their external environment is determined by fairly similar institutional conditions - the statuses «CATE», «single-industry city», «PDA».

Leading scientists have constantly considered the problems and prospects for the territories with a special organization of production and residence development. Thus, the Ural school of economic geography (Silin Y. P., Animitsa E. G., Vlasova N. Yu., Novikova N. V. and etc.) considers «single - industry cities» and «CATE« as historically established models of industrial development, and the «priority development areas», created on their basis as the entire Ural macroregion growth poles [2-5].

Also, within the framework of the Ural school of spatial economics (Dvoryadkina E. B., Efimova E. G.), a number of hypotheses were formed about the influence of the regional professional education system contribution over the country's economy labor potential formation [6].

In addition to the above-mentioned authors, the study of territories with a special organization of production and residence for the possibility of serving as a favorable environment for «man of today» development was conducted by the Metropolitan scientific school (Bogoviz A.V., Alekseev A. N., Kletskova E. V and etc.) [7].

Despite the numerous aspects related to the social policy formation in the territories under consideration, the issue of forming unified trajectories for the secondary vocational education institutions development has not been studied.

The law «On education in the Russian Federation» refers working out the program for the educational institution development to an educational organization competence. The 
main methodological approaches to education management today are program-target and project approaches.

Of particular interest are also the methodological recommendations published by the State Institute of New Forms of Education (Moscow) on the cluster interaction model implementation in the secondary vocational education system in the subjects of the Russian Federation, developed as part of the project commissioned by the Ministry of Education of the Russian Federation «Implementation of the cluster interaction mechanism in the system of secondary vocational education in the subjects of the Russian Federation» $[8,9]$. The testing of this method allowed to improve the management quality in more than three hundred educational institutions, but could not identify the trajectory of the management tools formation, taking into account territorial specifics.

The aim of the work is to determine the development targets of secondary vocational education (SPE) professional educational institutions, located in territories with a special organization of production and residence, taking into account the features of spatial placement in relation to the indicators of «Education» national project.

\section{Analysis of secondary vocational education institutions}

For the study, five municipalities, having three statuses at the same time, were identified: «CATE», «single-industry city» and «PDA». The cities of Zheleznogorsk, Ozersk, Snezhinsk, Zarechny, and Seversk are under «Rosatom» jurisdiction and are located in four regions of the Russian Federation.

Branches of the basic higher educational institution of the nuclear industry - the National Research Nuclear University MEPhI (NRU MEPhI) are located in the cities of Tomsk and Chelyabinsk regions. In Zheleznogorsk Siberian Fire and Rescue Academy is situated. A branch of the Penza State Technological University is located in Zarechny (Penza region), there are no secondary vocational educational institutions (SPE) in the city.

Comparative characteristics of territories are presented in Table 1. Informational sources concerning vocational schools were information and analytical materials based on the results of monitoring the personnel training quality in 2018 [10].

Monitoring was carried out taking into account 94 indicators, characterizing educational activities, the graduates' training level, infrastructure, financial and economic activities, teaching staff, graduates' employment, additional professional education programs implementation and social responsibility.

Table 1. Comparative characteristics of the municipalities

\begin{tabular}{|c|c|c|}
\hline City, region & $\begin{array}{l}\text { Population, } \\
\text { (thousands } \\
\text { of people) }\end{array}$ & $\begin{array}{l}\text { Secondary vocational educational institutions } \\
\text { (SPE) }\end{array}$ \\
\hline $\begin{array}{l}\text { Seversk, Tomsk } \\
\text { region }\end{array}$ & 106,5 & Seversk Industrial College (SPK) \\
\hline $\begin{array}{l}\text { Zheleznogorsk, } \\
\text { Krasnoyarsk Territory }\end{array}$ & 82,5 & $\begin{array}{l}\text { College of innovative industrial technologies and services } \\
\text { (TITPIS) }\end{array}$ \\
\hline $\begin{array}{l}\text { Ozersk, Chelyabinsk } \\
\text { region }\end{array}$ & 78,4 & $\begin{array}{l}\text { Ozersk Technical College (OzTK); } \\
\text { College of Ozersk Technological Institute (branch } \\
\text { of NRNU MPhi) (OTI NRNU MPhi); } \\
\text { Ozersk State College of Arts (OKI) }\end{array}$ \\
\hline $\begin{array}{l}\text { Snezhinsk, } \\
\text { Chelyabinsk region }\end{array}$ & 51,7 & $\begin{array}{l}\text { College of Snezhinsky Institute of Physics and } \\
\text { Technology (branch of NRNU MPhi) (SFTI NRNU } \\
\text { MPhi) }\end{array}$ \\
\hline $\begin{array}{l}\text { Zarechny, Penza } \\
\text { region }\end{array}$ & 65,6 & 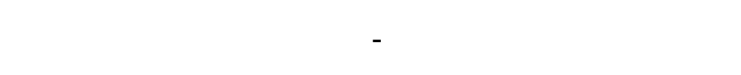 \\
\hline
\end{tabular}


19 monitoring criteria are the main ones. They are used to determine the position of educational institutions relative to the coordinate system " non-zero indicators number» and «number of indicators exceeding the median value», where the median value is determined by the middle of an ordered sample of non-zero indicator values within the industryspecific group. The most favorable position is that of the institution in the upper right quadrant, characterizing the highest degree of implementation and development of indicators.

The distribution of the analyzed educational institutions indicates a fairly high training level in institutions of the Chelyabinsk and Tomsk regions. An exception is the Ozersk State College of Arts, whose performance due to industry specifics is objectively lower than that of industrial-oriented educational institutions (Fig.1).

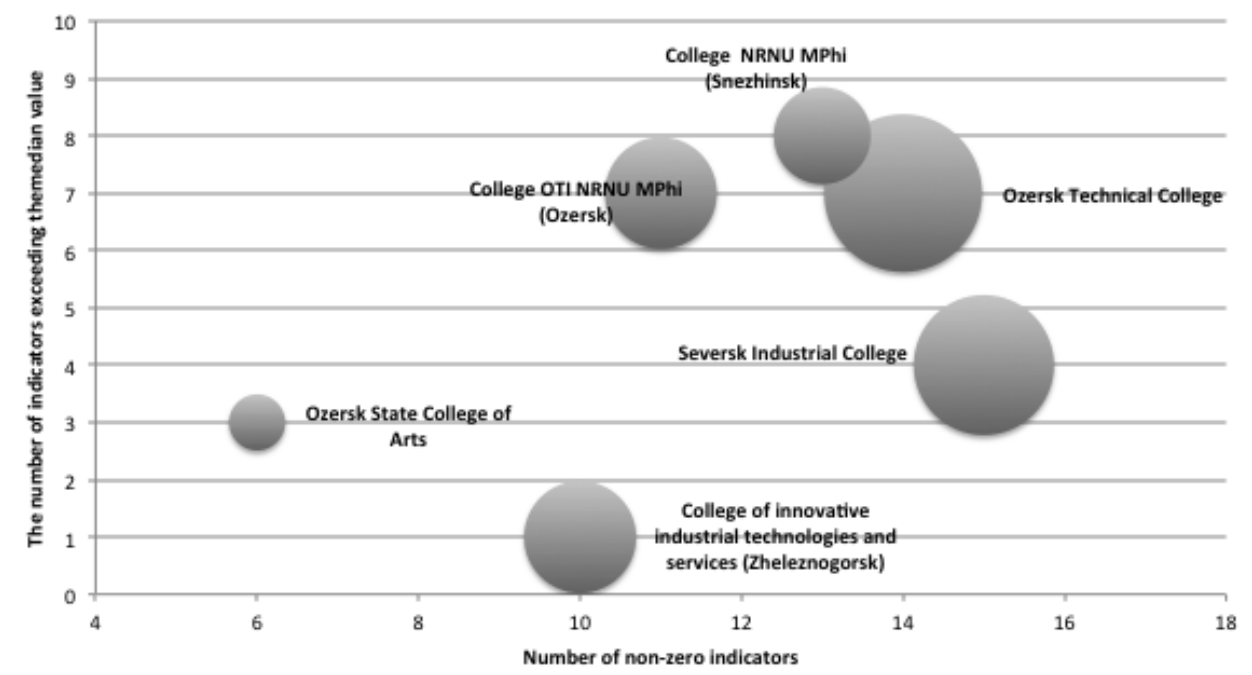

Note: the circle size corresponds to the given number of students

Fig. 1. Distribution of organizations based on achieving monitoring indicators results

College of Innovative Industrial Technologies and Services state (Zheleznogorsk) they was the worst among the analyzed educational institutions. The only indicator that is higher than the median value for this institution is the share of students studying in professions and specialties corresponding to the list of 50 most popular in the labor market, new and promising professions that require secondary vocational education (TOP-50).

Despite the fact that the College of Ozersk Technological Institute (branch of NRNU MPhi) does not have training areas in the TOP-50, its other indicators are significantly higher than other educational institutions have. The comparative characteristics of secondary professional educational organizations according to the main development criteria are presented in Table 2. 
Table 2. Comparative characteristics of professional educational institutions

\begin{tabular}{|c|c|c|c|c|c|c|}
\hline Indicators & $\underset{n}{U}$ & 此 & రิ & 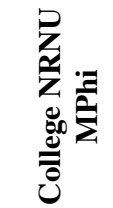 & 迎 & 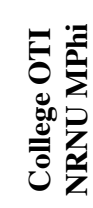 \\
\hline Students'number, (people). & 786 & 502 & 996 & 500 & 126 & 377 \\
\hline $\begin{array}{l}\text { For students, studying by TOP- } 50, \\
(\%)\end{array}$ & $27,48^{*}$ & $27,29 *$ & $34,27 *$ & 0 & 58,73 & $17,2 *$ \\
\hline Grade point average, (points) & 3,68 & 3,63 & 3,53 & $3,94 *$ & $4,17^{*}$ & $3,74 *$ \\
\hline $\begin{array}{l}\text { Prize-winners share in the total } \\
\text { students' number, who took part in the } \\
\text { «Young professionals» champion- } \\
\text { ships (WSR), }(\%)\end{array}$ & 40 & 0 & $80 *$ & 0 & 0 & 0 \\
\hline $\begin{array}{l}\text { The share of the machinery cost and } \\
\text { equipment not older than } 5 \text { years in } \\
\text { the total machinery cost and } \\
\text { equipment }(\%)\end{array}$ & 14,01 & 15,46 & 18,47 & $50,25 *$ & UN & $76^{*}$ \\
\hline $\begin{array}{l}\text { Machines and equipment, used for } \\
\text { educational purposes per student, cost } \\
\text { (thousand rubles). }\end{array}$ & 15,58 & 12,52 & $118,3^{*}$ & $149,06^{*}$ & UN & $267 *$ \\
\hline $\begin{array}{l}\text { Teachers' salaries ratio to the average } \\
\text { salary in the region's economy, }(\%)\end{array}$ & 99,39 & 94,57 & $112,7^{*}$ & $116,5^{*}$ & $125^{*}$ & $182 *$ \\
\hline $\begin{array}{l}\text { Share of the graduates' number who } \\
\text { were employed within one year after } \\
\text { completing their studies in the total } \\
\text { graduates' number }(\%)\end{array}$ & $60 *$ & 43,75 & 55,44 & $62,86^{*}$ & UN & 32 \\
\hline $\begin{array}{l}\text { Average graduates' salary ratio to the } \\
\text { average salary in the region's } \\
\text { economy }(\%)\end{array}$ & 58,93 & 64,89 & $67,37^{*}$ & $68,24 *$ & UN & $121 *$ \\
\hline
\end{tabular}

Note: * - indicators above median values. UN - unknown

\section{Targets for the educational organizations development}

A comparative analysis of organizations showed that Ozersk Technical College took the leading position. Its strategic development is based on a high degree of indicators formed implementation and development, taking into account the priority economic activities for the territory and the city-forming enterprise, which correlate with the list of the most popular professions on the labor market, the material and technical base development, as well as target indicators of regional projects.

These guidelines implementation in the development program allowed the college not only to fulfill the indicative indicators, but also to form a request and receive funding for equipping the modern material and technical base, which makes it possible to train graduates in popular specialties on the latest equipment. Social partnership with the cityforming enterprise «Mayak» industrial group («Rosatom» State Corporation) forms the college's developmental trajectory, including a specialized competence center «Welding technologies» and an industry competence center «Mechatronics» creation on its basis.

At Seversky industrial college in 2018, the most of the main indicators values did not exceed the median one. It indicates the phenomena characterized by indicators, the quantitative characteristics of which indicate the need for their development (optimization) 
presence in the educational organization. The weaknesses analysis allowed us to make adjustments to the college's development program, determine the priority direction (ITtechnologies), corresponding to both the concept of the innovative territorial cluster of the Tomsk region «Smart TechnologiesTomsk» and one of the main priorities of Seversk socio-economic development strategy until 2030 - the new information technology basis for the economy formation. The result of the modified college development program implementation was the receiving grant from the Ministry of Education of the Russian Federation in 2019, and the "Center for competencies development in the field of IT technologies» creation. Co-financing of this project was implemented by «Rosatom» State Corporation.

Colleges located in the cities of Ozersk and Snezhinsk on the basis of National Research Nuclear University MEPhI branches have high indicators in the rating mainly due to the good material and technical base of the head organization. The absence of TOP-50 specialities and professions in the Seversk Technological Institute college deprives the organization of additional funding sources and the possibility of developing students' professional competencies in accordance with international standards. In the college of Snezhinsky Institute of Physics and Technology the «WorldSkills» world championship movement, in parallel with the «AtomSkills» industry championship was actively developed since 2019, which brought prizes in the final of the VIII national championship «Young professionals» in the competence «Mobile robotics (junior)».

\section{Conclusions}

1. In the Russian Federation, there are a large number of territories with a special regime of production and residence, where professional educational organizations are located, which were created, as a rule, to train personnel for the city-forming enterprise. Defining targets for these educational institutions development requires taking into account the features of both spatial placement and «Education» national project indicators.

2. The objects of the analysis were professional educational institutions located in five municipalities that simultaneously have the status of a «closed administrative-territorial entity», a «single-industry city», and «priority development area» (Seversk, Ozersk, Snezhinsk, Zarechny, and Zheleznogorsk). Despite similar initial conditions, organizations develop along different trajectories, which are determined primarily by their management teams' competencies.

3. The determining factor of secondary vocational education training high quality in the studied organizations are the targets of the institutions developmental program, formed taking into account the priority areas and main enterprise economic activity that has a correlation with the list of the most in demand on the labor market professions, the material-technical base development, as well as target indicators of regional projects.

4. The study confirms the need for integration in development programs of SPE educational institutions design approach synthesis, taking into account developmental indicators of territories with the special organization of production and living, as well as the local stakeholders' interests and program-targeted approach focused on «Education» national project indicators.

\section{Acknowledgements}

The authors express their gratitude to the State Institute of New Forms of Education (Moscow) staff and personally to Melnichenko L. N. for mentoring, ideas and inspiration. 


\section{References}

1. T.V. Letaeva, A.A. Demin, Yu.V. Aleksakhina, Economy and entrepreneurship, 3, 1313 (2018)

2. Y.P. Silin, E.G. Animitsa, N.V. Novikova, Economy of the region, 13 (3), 684 (2017)

3. Y.P. Silin, E.G. Animitsa, N.V. Novikova, Manager, 2, 2 (2017)

4. E.G. Animitsa, V.N. Kuznetsov, O. T. Ergunova, The successes of modern science and education , 2 (12), 92 (2016)

5. N.Yu. Vlasova, Youth environment - a territory without extremism and terrorism. Materials of the International Scientific and Practical Conference (2017)

6. E.B. Dvoryadkina, Ye.G. Efimova, Manager, 10 (6), 28 (2019)

7. A.V Bogoviz., A.N. Alekseev, E.V. Kletskova, Y.V. Kuznetsov, T.Y. Cherepukhin, Access to Success, 19 (S2), 161 (2018)

8. Methodological recommendations on the implementation of a model of interaction in the vocational education system in the constituent entities of the Russian Federation, https://moodle.ginfo-edu.org/

9. L.N. Melnichenko, T.N. Shalkin, Technology of developing a program for the development of vocational education on the basis of project management (2018)

10. Information and analytical materials based on the results of monitoring the quality of personnel training in 2019, http://indicators.miccedu.ru/ 